\title{
DISCRIMINAÇÃO AMBIENTAL: DA PROTEÇÃO DAS MINORIAS EXCLUÍDAS PELA SOCIEDADE CONTEMPORÂNEA
}

\section{ENVIRONMENTAL DISCRIMINATION: PROTECTION OF MINORITIES EXCLUDED BY CONTEMPORARY SOCIETY}

\author{
Cleber Sanfelici Otero ${ }^{1}$ \\ Mithiele Tatiana Rodrigues ${ }^{2}$
}

\section{Resumo}

As pessoas, em suas existências, lutam para ser aceitas, ter reconhecimento na família, na sociedade ou em qualquer relação interpessoal. Na sociedade atual, como resultado do capitalismo e da globalização, há um padrão hegemônico em razão do qual muitos seres humanos estão excluídos socioambientalmente. Pessoas que já estavam em situação de desamparo, agora também sofrem uma nova exclusão, denominada nesta pesquisa de "discriminação ambiental". Ela vai além do preconceito e do racismo, ante as ações ou omissões com fim de prejudicar, e que extrapolam as questões meramente raciais e étnicas no referente a desigualdades e injustiças. O Direito precisa dirimir as desigualdades e os fatores de discriminação, implementando ações afirmativas com escopo de ofertar a todos o mínimo essencial para viver. O propósito deste trabalho é mostrar a existência dessa maior vulnerabilidade. Com análise da literatura jurídica, a pesquisa emprega o método de abordagem dedutivo e dos métodos de procedimento histórico e comparativo, para demonstrar que o ambiente saudável - inferido como direito fundamental a partir de normas constitucionais implica o respeito à dignidade para o desenvolvimento da pessoa, algo pouco observado até tempos recentes a ponto de acarretar a agora reconhecida discriminação ambiental.

Palavras-chave: Discriminação; Meio ambiente; Vulnerabilidade; Personalidade; Reconhecimento e aceitação

\begin{abstract}
The persons, in their existences, struggle to be accepted, to have recognition in the family, in society or in any interpersonal relationship. In today's society, as a result of capitalism or globalization, there is a hegemonic pattern on the basis of which many human beings are excluded socio-environmentally. Those persons who were already in situation of helplessness, now also suffer a new exclusion, denominated in this research of "environmental discrimination". It goes beyond prejudice and racism, in the face of acts or omissions that are prejudicial and that go beyond purely racial and ethnic issues regarding inequalities and injustices. The law must resolve the inequalities and the factors of discrimination, implementing affirmative actions with scope to offer everyone all the basic essentials. The purpose of this

\footnotetext{
${ }^{1}$ Doutor em Sistema Constitucional de Garantia de Direitos pela ITE de Bauru-SP. Docente do Curso de Mestrado, Especialização e Graduação em Direito do Centro Universitário Cesumar - UNICESUMAR (Maringá/PR). Docente do Curso de Especialização em Direito Previdenciário da UEL (Londrina/PR). Email: cleberot@yahoo.com.br

${ }^{2}$ Mestre pela UNICESUMAR (Maringá/PR). Professora de Direito Constitucional na Faculdade Alvorada de Tecnologia e Educação (Maringá/PR). E-mail: mithielerod@gmail.com
} 
paper is to show the existence of this greater vulnerability. With an analysis of the legal literature, the research employs the deductive method of approach and the historical and comparative methods of procedure to demonstrate that the healthy environment - inferred as the fundamental right from constitutional norms - implies respect to the dignity to development of the person, something barely noticed until recently as a way that led to the presently recognized environmental discrimination.

Keywords: Discrimination; Environment; Vulnerability; Personality; Recognition and acceptance

\section{INTRODUÇÃO}

Para o ser humano desenvolver suas potencialidades e crescer com saudável desenvolvimento da sua personalidade, é imprescindível que ele esteja inserido num ambiente externo equilibrado.

O escopo deste trabalho é a compreensão da discriminação ambiental sofrida pelas pessoas que se encontram em situação social de vulnerabilidade, discriminação esta decorrente de fatores culturais, sociais, políticos e econômicos, de modo a fazer com que pessoas da sociedade sejam segregadas por não se encontrarem em adequação com os padrões ideais estabelecidos principalmente em razão da globalização.

Costuma-se chamar esta discriminação de "racismo ambiental", mas prefere-se empregar neste estudo a expressão "discriminação ambiental", por ser mais adequada, porquanto o problema não seria propriamente de racismo, ainda que seja este compreendido em sentido amplo, mas de discriminação em face de ações e omissões praticadas deliberadamente em detrimento de pessoas ambientalmente vulneráveis.

O meio ambiente ecologicamente equilibrado não só consagra a vida como também propicia a saúde e condições hábeis para que o ser humano desenvolva suas capacidades mentais, físicas e psicológicas. Por essa razão, o meio externo deve ser o mais sadio possível.

Realiza-se uma análise jurídica dos aspectos do meio externo como influenciador no desenvolvimento da personalidade, com o estudo da importância do meio externo salubre e das possíveis consequências de um meio ambiente em desequilíbrio. A vida cotidiana sofreu alterações, o homem mudou e a sociedade tem passado por profundas transformações, mudanças estas que refletem, de uma maneira ou outra, na pessoa, inclusive vindo a refletir na discriminação por sexo, raça, cor, etnia, sofrida pelas minorias, principalmente em razão de um padrão imposto na sociedade. 
A pesquisa parte do estudo da relação entre personalidade e direitos da personalidade, bem como da premissa de que o ser humano nasce com a pretensão de ser aceito pelo outro, motivo pelo qual da não aceitação surge a rejeição e, consequentemente, dela são oriundos diversos sintomas psicossociais.

O ambiente em que a criança se desenvolve é extremamente relevante, pois constatase ter a pessoa que cresce em condições ambientais saudáveis mais chances de ser alguém com hábitos adequados para um bom desenvolvimento, seja em aspectos pessoais, sociais ou psicossociais. Ao revés, as pessoas que crescem em ambientes degradados (como em morros, lixões e aterros sanitários), poluídos ou ecologicamente desequilibrados têm uma tendência de desenvolver doenças, sintomas psicológicos e até comportamentos sociais incompatíveis, inclusive a admissão ao tráfico de drogas e crimes violentos, muito em razão da decorrente falta de oportunidades de inserção social.

Um Estado Democrático de Direito não poderia tratar todos de forma exatamente igual, uma vez que cada ser humano e cada grupo tem as suas particularidades e sensibilidades. A isonomia, todavia, não pode ser negligenciada como critério garantidor de justiça, pois o que todos querem é a inclusão, ou seja, a inserção de forma digna na sociedade, na família e estarem em paz consigo mesmos, porque, antes de aceitar o outro, é preciso aceitar-se a si mesmo, algo que também envolve uma relação com o ambiente.

Para cumprir a finalidade a que se propõe neste trabalho, realiza-se uma análise da literatura jurídica, com a metodologia de abordagem dedutiva e de procedimento histórico e comparativo para demonstrar que o direito ao meio ambiente saudável, reconhecido como direito fundamental a partir de normas constitucionais, implica o dever de respeito à dignidade para o desenvolvimento da pessoa, o que não se observava até tempos recentes a ponto de gerar a ora denominada discriminação ambiental.

\section{DIGNIDADE HUMANA, DIREITO À VIDA DIGNA E DIREITO AO MEIO AMBIENTE EQUILIBRADO}

A Constituição da República Federativa do Brasil de 1988, no art. 5o, estabelece a vida como direito fundamental e, no art. 225, dispõe que "todos têm o direito ao meio ambiente ecologicamente equilibrado [...]" (BRASIL, 1988). Frisa-se, portanto, que não basta ter a vida, pois ela deve ser vivida de forma saudável, consoante um dos fundamentos do Estado 
Democrático de Direito brasileiro, a saber, a dignidade da pessoa humana, assim prevista no art. 1ำ, inciso III, da Constituição de 1988.

A compreensão da dignidade humana decorre de um desenvolvimento conceitual havido desde a Antiguidade, a partir do monoteísmo hebraico, do cristianismo e na filosofia greco-romana, com um primeiro registro da expressão atribuído a Cícero (BARROSO, 2013, p. 14-15). No Medievo, a dignitas humanas foi referenciada no sistema tomista em face da potência humana do livre arbítrio, capaz de aproximar o homem da divindade, diversamente dos demais seres (TOMÁS DE AQUINO, 1980, p. 676, 733 e 813), o que veio a permitir, posteriormente, no humanismo, um novo contorno, centralizado e vinculado à razão e à escolha própria de uma conduta autônoma do ser humano, conforme se observa na obra de Pico della Mirandola (2006, p. 53, 57 e 65-69).

Com Kant, já no lluminismo, é que se perfez a dignidade humana em uma filosofia ética, que abandonou completamente a concepção religiosa para a dignidade restar reconhecida ontologicamente como inerente ao ser humano.

Para Kant (2006, p. 27-29 e 51), como o "o dever é a necessidade de uma ação por respeito à lei" e dele decorre uma legalidade universal das ações em geral com o princípio da vontade "devo agir sempre de modo que possa querer também que minha máxima se converta em lei universal, é possível reconhecer, por ser inerente ao ser humano, uma razão pura prática (a priori) capaz de direcioná-lo no sentido de adotar uma conduta ética ao agir, inclusive contrária aos seus interesses pessoais (KANT, apud OTERO, 2011, p. 149). Logo, ao contrário dos outros seres, cujos destinos não estão na vontade, mas na natureza, o homem, por ser racional, é ser digno, tem fim em si mesmo e não pode ser meio para uso arbitrário desta ou daquela vontade, de maneira que todas as pessoas merecem o devido respeito em conformidade com o imperativo prático "age de tal maneira que possas usar a humanidade, tanto em tua pessoa como na pessoa de qualquer outro, sempre e simultaneamente como fim e nunca simplesmente como meio" (KANT, 2006, p. 59)

O conceito kantiano é o que melhor permite compreender o homem como ser digno e, como decorrência, a dignidade humana havida na incorporação jurídica, a partir da qual se parte a orientação normativa (deontológica) para a interpretação de todo o sistema normativo, consoante se observa doravante no presente trabalho.

Própria do ser, a dignidade humana foi incorporada nos ordenamentos jurídicos em norma principiológica aberta, que vincula a sociedade como um todo em torno de especial valoração, de forma a conferir sustentação nuclear aos direitos fundamentais, ser cláusula geral 
dos direitos fundamentais e da personalidade, além de permitir uma orientação do ordenamento em consideração e proteção da pessoa como titular de direitos essenciais.

O avanço quanto ao papel desempenhado pelos direitos fundamentais no âmbito do Estado constitucional teve como ponto de partida a indissociável vinculação entre os direitos fundamentais e as noções de Constituição e Estado de Direito, aparecendo no Bill of Rights inglês de $1689^{3}$ e, depois, de forma mais incisiva e escrita em texto constitucional, na Declaração de Direitos da ex-colônia inglesa da Virgínia em 1776 e, na sequência, em França, na Declaração dos Direitos do Homem e do Cidadão de 1789 (SARLET, 2015, p. 43).

Os direitos fundamentais nasceram, para proteger as pessoas da atuação estatal arbitrária, como direitos de liberdade, v.g., liberdades de locomoção, religiosa e de crença, profissional, etc. Posteriormente, no início do século XX, sobrevieram direitos sociais, mais relacionados à igualdade, estabelecidos para assegurar proteção aos trabalhadores nas relações trabalhistas, bem como por meio de prestações estatais. A partir de meados do século passado, tiveram notoriedade os direitos referentes à solidariedade, normalmente direitos difusos e coletivos, v.g., direito ao meio ambiente, do consumidor, etc.

O reconhecimento do meio ambiente como direito fundamental decorrente de norma constitucional ocorreu em tempos mais recentes, primeiramente na Alemanha em 1949, depois na Suíça em 1957, na Bulgária em 1971, em Portugal em 1976, na União Soviética em 1977, no Chile em 1981 e na China em 1982 (SILVA, 2013, p. 46-49). No Brasil, apenas após a Constituição da República Federativa do Brasil de 1988 é que se conferiu à matéria ambiental um tratamento amplo e moderno, em capítulo específico sobre o meio ambiente, inserido no Título da "Ordem Social" (SILVA, 2013, p. 49).

O art. 225, caput, da Constituição Federal de 1988 estabelece: "Todos têm direito ao meio ambiente ecologicamente equilibrado, bem de uso comum do povo e essencial à sadia qualidade de vida, impondo-se ao Poder Público e à coletividade o dever de defendê-lo e preservá-lo para as presentes e futuras gerações" (BRASIL, 1988). Por "todos", na verdade, entende-se não só o conjunto integrado pelos brasileiros e estrangeiros residentes no país, mas efetivamente todas as pessoas, inclusive estrangeiros de passagem pelo território brasileiro, por se tratar de direito difuso e de um bem juridicamente protegido em prol de cada indivíduo que entrar em contato com o meio ambiente, salientando que "a negação de titularidade de direito

\footnotetext{
${ }^{3}$ Na Inglaterra, a Magna Carta assinada pelo Rei João Sem Terra em 1215 foi um precedente relevante, mas mais limitado aos direitos dos barões feudais e do clero.
} 
[fundamental] a outros seres vivos não implica, automática e inevitavelmente, negação de reconhecimento de seu valor intrínseco" (CANOTILHO; LEITE, 2007, p. 206)

Na legislação infraconstitucional, o art. 3o, inciso I, da Lei no 6.938/81 conceituou meio ambiente como "o conjunto de condições, leis, influências e interações de ordem física, química e biológica, que permite, abriga e rege a vida em todas as suas formas" (BRASIL. 1981). Esse conceito só abrangeria o meio ambiente natural, mas a doutrina, sob a sustentação de haver deficiência, fez ampliar o conceito para o fim de abarcar também o meio ambiente natural, artificial e do trabalho (SIRVINSKAS, 2014, p. 155), muito embora, mais recentemente, pretenda-se apartá-lo da ideia de ambiente cultural.

O Direito Ambiental é o conjunto de normas (princípios e regras) reguladoras das relações entre as pessoas físicas e jurídicas com o meio ambiente, disciplinando a utilização dos recursos ambientais em aspectos econômicos, sociais e ecológicos para assegurar um desenvolvimento sustentável (ANTUNES, 2014).

$\mathrm{Na}$ Constituição brasileira, o direito ao meio ambiente e à qualidade de vida implicam uma união conceitual de direito à vida digna, transformando-se em direito fundamental. Por essa razão, muitas Constituições - e, nesse particular, também a brasileira - passaram a proteger a vida de forma mais intensa como garantia da coletividade (MACHADO, 2005, p. 119).

Ao contrário do que se possa pensar, não se confunde vida e dignidade, porquanto são direitos autônomos, por vezes, em algumas situações, até mesmo conflitantes, como, por exemplo, nas hipóteses de interrupção da gravidez (SARLET, 2012, p. 354), seja em razão de estupro, má-formação ou de anencefalia, conforme se observa agora no Direito brasileiro. Apesar da ligação entre vida e dignidade de forma a resultar a noção de um direito à vida digna, também não cabe a confusão entre dignidade humana com vida digna, pois a dignidade é inerente ao ser humano, ao passo que viver dignamente pode resultar, por vezes, de uma opção por parte da pessoa, que pode preferir viver mal, mesmo tendo recursos. Em verdade, a partir do direito à vida tem-se o reconhecimento do direito a uma vida digna, mas que diz respeito a obrigações positivas do Estado e da sociedade para com as pessoas no pertinente ao mínimo existencial (SARLET, 2012, p. 352-353).

A valorização da vida como valor supremo, como faz logo de início a Constituição Federal ao consagrar o direito à vida e o resguardo à dignidade da pessoa humana, tem por finalidade viabilizar a realização plena do potencial produtivo e criativo intrínseco de cada indivíduo, impondo, ao mesmo tempo, aos seres humanos, o dever de preservar o lugar em que 
vivem (BARBOSA, 2012, p. 58), não por ser um exclusividade da pessoa, mas especialmente porque o meio ambiente é um interesse difuso.

Milaré e Loures (2005, p. 12-14) chegam a lecionar que, em correlação ao elenco de direitos e deveres individuais e coletivos do art. 5ㅇ, e ante o disposto no $\S 2$ 을 do mesmo dispositivo, tem-se, na norma do caput do art. 225 da Constituição de 1988, um novo direito humano fundamental, estabelecido para assegurar condições de vida adequadas em um ambiente "ecologicamente equilibrado" e saudável para as pessoas.

A característica da complementaridade entre os direitos fundamentais reforça este entendimento. Como exemplo, pode-se até mesmo falar em transcendência do direito à vida, uma vez se poder deduzir do ordenamento jurídico constitucional que o indivíduo tem direito não simplesmente à vida, mas à qualidade de vida (SILVA, 2013, p. 51), isto é, a uma vida digna, para a realização plena da personalidade humana, algo que envolve boas condições ambientais, também.

A personalidade é uma unidade físico-psico-ambiental, que coordena e assume as suas funções e é composta por elementos, internos e ambientais, fundidos em um conjunto que os ultrapassa, os referencia e os projeta, com uma dinâmica própria, de maneira que a identificação de um bem da personalidade reflete apenas o mais imediato corte setorial da personalidade, porquanto a sua maior compreensão exige a consideração de outros setores interligados com aquele bem:

[...] para além dessa unidade psico-somática, toda personalidade humana é um ser com uma estrutura mais alargada, de teor relacional, sócioambientalmente inserida e que abarca dos pólos interativos: o 'eu' (enquanto conjunto de funções e potencialidades de cada indivíduo) e o mundo (tomado este, quer do ponto de vista psicológico interno, como objeto ou conteúdo sobre que incide a vida psíquica personalizada, quer ainda, no plano da actividade relacional, como o próprio conjunto das forças ambientais em que se situa cada indivíduo), tudo o que se encontra igualmente protegido na ideia de 'personalidade moral' [...]. (CAPELO DE SOUSA, 2011, p. 199-200)

O direito à uma vida digna implica sejam asseguradas condições suficientes para a pessoa viver com o mínimo necessário para uma existência digna, contribuindo, para tanto, os direitos para que cada ser humano possa desenvolver a sua personalidade. Não por acaso, Capelo de Sousa (2011, p. 99) faz referência a normas de tutela de direitos da personalidade no âmbito das tarefas estatais, inclusive com o reconhecimento de direitos públicos subjetivos outorgados na área de segurança, assistência social, saúde, habitação, ambiente, qualidade de vida, ensino, cultura, que deixam de exprimir a ideia de caridade pública para traduzir o 
reconhecimento da dignidade humana e do direito ao mínimo necessário à existência física e espiritual.

Ante o respeito à dignidade humana, a proteção constitucional ao meio ambiente confere reforço para assegurar a qualidade de vida como direito:

A normativa constitucional afirma que todos têm direito ao meio ambiente, mas não a qualquer ambiente e sim ao meio ambiente equilibrado. Integra, portanto, a esfera jurídica dos sujeitos de direito ao equilíbrio ambiental. Nessa linha de amarração, qualquer um que viole tal normativa está a violar direitos subjetivos de sujeitos. O raciocínio que aqui se estampa se prende ao plano da eficácia da norma e certamente não se vincula a uma titularidade proprietária. O direito ao ambiente ecologicamente equilibrado é direito subjetivo de ordem material e alcança seara dos direitos fundamentais. (MILARÉ; LOURES, 2005, p. 17)

Nesse magistério, de que o direito ao equilíbrio ambiental integra a esfera jurídica dos sujeitos, percebe-se a intenção de consolidar o direito fundamental à qualidade de vida, bem como o direito à sua defesa para manter protegida a personalidade (BARBOSA, 2012). Afinal, a preservação do equilíbrio ecológico é condição (conditio sine qua non) sem a qual não há qualidade de vida, por ser o direito ao ambiente ecologicamente equilibrado pressuposto lógico e inafastável da realização do direito à sadia qualidade de vida (MILARÉ; LOURES, 2013, p. 16. AMARAL; GOMES, 2012). Daí também se concluir que a simples caracterização das normas constitucionais destinadas à proteção da dignidade humana já justificaria o direito da pessoa ao meio ambiente ecologicamente equilibrado (BARBOSA, 2012, p. 59).

Com efeito. A pessoa não só está inserida no meio, mas o ambiente está em cada pessoa, tanto que pode transformá-la, seja em relação a doenças geradas por bactérias e vírus que passam a afetar o organismo humano, ou com a absorção de elementos necessários para viver e se desenvolver, inclusive no que diz respeito à alteração de características individuais, porquanto da interação genótipo-ambiente advém o fenótipo.

O Supremo Tribunal Federal, na qualidade de intérprete maior da Constituição, já se manifestou sobre a matéria e também reconheceu a fundamentalidade do direito ao meio ambiente (AMARAL; GOMES, 2012), consoante assim restou julgado em 1995:

O direito ao meio ambiente ecologicamente equilibrado - direito de terceira geração - constitui prerrogativa jurídica de titularidade coletiva, refletindo, dentro do processo de afirmação dos direitos humanos, a expressão significativa de um poder atribuído não ao indivíduo identificado em sua singularidade, mas num sentido verdadeiramente mais abrangente, a própria coletividade social. [...]. Os direitos de terceira geração, que materializam poderes de titularidade coletiva atribuídos genericamente a todas as formações sociais, consagram o princípio da solidariedade e constituem um momento importante no processo de 
desenvolvimento, expansão e reconhecimento dos direitos humanos, caracterizados enquanto valores fundamentais indisponíveis, pela nota de uma essencial inexauribilidade. (BRASIL, 1995)

Esta posição foi reafirmada em 2005, ao se ratificar o novo direito fundamental (BRASIL, 2006), que, por seu caráter de coletividade e solidariedade, pode ser considerado anterior à própria dignidade, já que existe para garantir o direito à vida (AMARAL; GOMES, 2012, p. 165184). A tutela da qualidade do meio ambiente é instrumental, no sentido de que, por meio dela, busca-se a proteger um valor maior: a qualidade da vida (AMARAL; GOMES, 2012, p. 165-184).

Nessa toada, os direitos fundamentais de terceira geração, como é o caso do direito ao meio ambiente, trazem uma importante nota distintiva: visam à proteção de interesses coletivos e difusos. Transcendem a titularidade individual, porquanto não se referem apenas à tutela do homem enquanto indivíduo, mas sim à proteção de grupos humanos (AMARAL; GOMES, 2012). E mais, um necessário reconhecimento constitucional para a proteção não só da presente, mas também das gerações futuras, que implica obrigações jurídicas para as pessoas, tanto individual como coletivamente (PRIEUR, 2004, p. 62-66).

Destaca-se a existência de um vínculo de solidariedade social, com a tutela de um interesse difuso, transindividual, que, nas palavras de Fiorillo (2013, p. 62), pertence "a todos e a ninguém ao mesmo tempo", um ideal solidário em torno desse direito não só com os nossos contemporâneos, mas também com as futuras gerações. No enunciado normativo, estão presentes os princípios da solidariedade e do desenvolvimento sustentável.

O meio ambiente referido no art. 225 da Constituição de 1988 não abrange somente elementos naturais (água, ar, solo, flora e fauna), mas também os aspectos artificiais e culturais, incluindo a estética da paisagem natural e o ambiente construído pelo homem, cuja interação propiciam o desenvolvimento equilibrado da vida em todas as suas formas. $\mathrm{O}$ direito ao meio ambiente equilibrado ainda diz respeito à "inapropriabilidade", inalienabilidade, imprescritibilidade e à inexistência de um direito adquirido à poluição ou à degradação ambiental (KRELL, 2013, p. 2080). Ele não ocupa uma posição de preferência absoluta em relação a outros bens jurídicos e interesses, mas, como todos os direitos fundamentais, ele constitui um direito prima facie e atinge os seus contornos definitivos na relação de reciprocidade com outras características e com outras categorias de direitos consagrados no texto da Constituição Federal (KRELL, 2013, p. 2080).

A inserção constitucional da matéria ambiental é ressaltada: 
A Constituição Federal de 1988 expressamente dispõe que o meio ambiente deve ser tutelado não só para a presente geração, mas também para as futuras gerações. Além dessa redação denotar um senso de continuidade e união [por meio do princípio da "transgeracionalidade"], relevantes ao se tratar de meio ambiente, está ínsito nela um elemento ético. Afinal, as futuras gerações arcarão com as escolhas que se fazem hoje, produto de visões e interesses político-culturais atuais, sem, contudo, participarem do processo decisório, quando se sabe que as ações de hoje traçarão o futuro do amanhã.

Trata-se da Constituição Ambiental do Brasil, ou "Constituição Verde", que tem como fundamental a questão ambiental, reconhecendo, assim, que a dignidade só pode subsistir se houver também o equilíbrio ambiental, a saúde e a preservação da biodiversidade. (AMARAL; GOMES, 2012)

Excelente seria se a proteção jurídica fosse solução suficiente e definitiva para esta demanda, mas o tema ambiental também se processa no mundo dos fatos e, infelizmente, neste, demanda outras formas de controle e de respostas, como uma fiscalização mais intensa, políticas públicas, educação e conscientização. Afinal, as atividades do homem não devem ser orientadas apenas por interesses materiais, pois, cada vez mais, revela-se que o crescimento econômico não é a solução para os problemas, mas, muitas vezes, é a própria origem deles.

Em suma, nas palavras de Krell (2013, p. 2083), a consagração do direito ambiental em nível fundamental determina que ninguém poderá tratá-lo como valor subsidiário, acessório, menor ou desprezível. Assim, possui, como efeitos, os seguintes: 1) ele reduz o espaço de livre conformação do legislador; 2) é um dado importante para a interpretação axiológica para as leis; 3) leva a uma proibição de retrocesso ambiental, vedando ao poder estatal tomar medidas que diminuam o nível de proteção normativa alcançado; 4) concede ao cidadão o direito ao mínimo existencial ecológico, judicialmente exigido e correspondente a um núcleo essencial do direito ao meio ambiente e à qualidade de vida.

\section{DA LIBERDADE À IGUALDADE PARA POR FIM ÀS MISÉRIAS EXTREMAS}

Muito embora uma sociedade seja formada pela união de pessoas, cada indivíduo tem suas peculiaridades, sua língua, seus costumes, seus credos, suas origens, e, por tais características, percebe-se uma heteronomia entre os cidadãos.

Um dos motivos que levam os homens a guerras e revoluções é justamente a insatisfação social, pois o objetivo é diminuir a separação bruta visível entre classes sociais, para que, então, as sociedades estratificadas se diluam e os seres humanos se aproximem uns dos 
outros, ou que, pelo menos, essa distância entre um e outro não seja um abismo, como seu viu por séculos.

As lutas, sejam elas físicas, psicológicas, ou sociais, apresentaram-se conforme a época em que uma sociedade estava inserida. Como o direito regula o comportamento dos homens em sociedade e a estruturação da mesma, ele deve ser compreendido em conformidade com a sociedade que o gerou. Na sociedade pré-histórica, por exemplo, fundamenta-se no princípio do parentesco, nos laços consanguíneos, nas práticas de convívio familiar de um mesmo grupo social, unido por crenças e tradições (LUHMANN, 1983, p. 182-184). Na sociedade arcaica, o conceito de pessoa era desconhecido para o homem, da mesma forma que a personalidade, e, por consequência, a dignidade, preceitos esses que posteriormente mudariam completamente a vida em sociedade.

O que faz uma sociedade se formar é a comunicação, o vocabulário, as práticas, os costumes, os hábitos, a religião, os conceitos, as classificações, as categorias, as técnicas, os métodos. Esse conjunto faz com que cada povo se agrupe com outros países de traços semelhantes em certos sistemas ou famílias, o que influenciará também a forma pela qual se cria, se aplica e se ensina o Direito (MERRYMAN, apud ABBOUD; CARNIO; OLIVEIRA, 2013, p. 215).

Primeiramente, o ser humano se reconhece como um indivíduo, um ser singular, para somente depois desse reconhecimento passar a se relacionar com os outros. E, quando entra em contato com o outro, pode haver conflitos, porquanto existe a necessidade de ter interação social.

Os aspectos gerais da igualdade aproximam os homens pelo fato de serem da mesma espécie, mas a característica inversa e singular entre eles pode agrupá-los ou afastá-los uns dos outros, com a formação de tribos, grupos, comunidades e assim por diante. A existência de pessoas diferentes, que não pertençam ao grupo hegemônico, pode ensejar o aparecimento de pessoas ou de grupos em situação de vulnerabilidade, bem como de minorias, quando a ideia de exclusão dos diferentes passa do âmbito particular para as coletividades (OTERO, 2011, p. 23).

No mesmo povo ou em um mesmo território, haverá pessoas que não seguem os mesmos padrões, que não são iguais à maioria. Por vezes, esses grupos, que são vistos como diferentes, ou ainda passam por invisíveis em um meio, precisam encontrar condições para que seus membros possam se desenvolver como cidadãos, como seres humanos, em relação ao outro e também consigo. 
Uma sociedade não se forma com pessoas que possuam exatamente o mesmo padrão social, a mesma cultura, as mesmas origens. Há uma miscigenação de fatores, que culminam na redução de comunidades, grupos e classes, ocasionando um distanciamento entre as pessoas pertencentes à maioria em relação àquelas tidas como minorias (BITENCOURT NETO, 2010, p. 20-40).

Para reverter o processo de exclusão, a sociedade democrática tem o dever de colocar à disposição de todos os cidadãos os direitos e garantias essenciais conquistados ao longo da história, de maneira a tratar os cidadãos com isonomia, ou seja, na conformação de uma igualdade com o cunho de justiça social. O Estado Democrático de Direito só se torna concebível com a efetivação do princípio da igualdade, direito fundamental conquistado com lutas que remontam a séculos.

\section{Do direito solidário para a proteção dos vulneráveis}

O que se espera de um Estado de Direito é disponibilizar a todos os cidadãos o acesso aos direitos fundamentais ou, pelo menos, ao mínimo de direitos fundamentais para se viver com dignidade. Significa isso tratamento isonômico, muito longe de caracterizar comunismo. O propósito é assegurar a promoção e a realização da justiça social.

Na concepção de justiça como equidade de John Rawls (2005, p. 398-399), delineia-se a situação hipotética de igualdade originária em que os indivíduos escolhem as normas de regência de sociedade em formação, com a probabilidade de não aceitarem o princípio de utilidade, pois este asseguraria maior quantidade de benefícios para alguns em detrimento da perda pessoal duradoura para os outros, de maneira que viriam a escolher a igualdade na atribuição de direitos e deveres fundamentais e, também, um princípio segundo o qual as desigualdades econômicas e sociais apenas seriam justas se produzirem benefícios compensatórios para cada um e, em particular, igualmente para os membros menos favorecidos da sociedade. A posição originária descrita por Rawls é utópica, mas a abstração permite realçar o ideal do que as pessoas compreendem como justo.

Sempre se soube que as pessoas são, no mundo real, diferentes. Umas nascem em castas cheias de privilégios ou em famílias da classe social mais abastada, com condições financeiras, culturais e sociais, em detrimento de outras, que nascem desamparadas financeira e, muitas vezes, afetivamente. É, de fato, um mundo cheio de pessoas desiguais. 
Segundo Dworkin (1999, p. 360), a igualdade é tratada como direito de ser igual, segundo o qual a distribuição de oportunidades seria derivada de uma igualdade de respeito e consideração. Trata-se de premissa necessária para a compreensão do tema.

Com a desestruturação das corporações de ofício e o aparecimento da sociedade industrial, os artífices ficaram livres para negociar a respectiva força de trabalho, mas, com a exploração da mão-de-obra, o avanço do capitalismo e a falta de representação política, os operários se tornaram fracos e excluídos. Assim, a liberdade, alcançada com a derrubada da sociedade estamental, favoreceu o acúmulo de riqueza pela burguesia e excluiu os proletários, chegando a debilidade econômica a implicar tamanha desigualdade que reduziu sobremaneira a própria liberdade.

O Estado assumiu, então, cada vez mais, desde a alvorada do século XX, um dever prestacional, de dar condições de desenvolvimento a todos, principalmente para as pessoas que se encontram em situação de distanciamento dos grupos hegemônicos, seja por motivos econômicos, culturais, sociais, políticos, religiosos, seja pela força de opressão social, seja pela sua incapacidade de defesa, ou qualquer outra situação de discriminação.

Conforme o magistério de Barroso (2013, p. 85), as pessoas, para serem livres, iguais e capazes de exercer uma cidadania responsável, precisam estar além dos limiares mínimos de bem-estar, sob pena de a autonomia se tornar ficção e a dignidade deixar de existir, daí a necessidade de o Estado assegurar o acesso a prestações essenciais, como a educação básica, saúde, alimentação, vestuário, água e abrigo. Para aqueles que estão em situação de vulnerabilidade, a liberdade e a autonomia passam a depender de anteriores medidas de integração na sociedade, além do acesso a bens e serviços.

Para tanto, em tempos mais recentes, a atuação estatal passou a se fundar na dignidade humana, o princípio motriz do ordenamento jurídico, mas ela não se mostra ainda suficiente na prática para que a igualdade e a não discriminação realmente estejam presentes no cotidiano dos cidadãos. Isso se verifica, principalmente, na vida daqueles que se encontram em uma posição de fragilidade ou são integrantes das minorias excluídas.

Por tal motivo, dessas circunstâncias resulta a necessidade de uma nova construção jurídica para assegurar o respeito às pessoas, principalmente as que estão em situação de vulnerabilidade no meio ambiente em que se encontram. 


\section{Da incapacidade de autoproteção por parte dos vulneráveis}

Quando se fala em minorias, a impressão que se tem é que o termo faz referência a grupos de indivíduos excluídos. De fato, eles o são, porém não se trata somente disso, pois são pessoas, na maior parte das vezes, que não têm condições de se protegerem nem de administrarem suas vidas, encontram-se vulneráveis, ou seja, são dependentes de uma tutela estatal e, por vezes, de políticas públicas.

As minorias, em geral, têm em comum o fato de não se protegerem de forma autônoma e independente, em especial porque, como os negros, já carregam, no berço histórico, estigmas.

Percebe-se que as mulheres já estão galgando seu espaço na sociedade, contudo apenas um segmento de mulheres bem-sucedidas, independentes e autônomas, que estão na classe social privilegiada, o mesmo não ocorrendo, com certa amplitude, acerca das mulheres que se encontram na classe pobre, ou menos favorecida.

As minorias e grupos vulneráveis, como os refugiados de guerra, as pessoas com deficiência, moradores de rua, imigrantes, negros, quilombolas, índios, ainda necessitam, cada qual, de peculiar proteção, uns com menos grau de intensidade, outros com mais.

O maior problema da falta de voz inerente a essa minoria não diz respeito ao seu "querer", pois é fato histórico que também há pessoas sem o desejo de fazer parte da sociedade, v.g., é o caso de muitos mendigos, vadios, etc. No entanto, mesmo essas pessoas, que se recusam a entrar no "sistema" e preferem viver na rua, em lixões, devem ser tuteladas pelo Estado, pois, sobretudo, antes de serem mendigos, são seres humanos.

O Estado deve disponibilizar a essas pessoas, mesmo contra as suas vontades, o mínimo existencial para viverem dignamente. É preciso, no entanto, que estas minorias ou indivíduos de grupos socialmente vulneráveis compreendam o que vem a ser dignidade, porquanto, provavelmente, as pessoas que deles tomam parte desenvolveram sua personalidade sem essa compreensão, principalmente em virtude do afastamento das mesmas.

É nessa premissa que paira a afirmação de não estar o "querer" em análise, pois a pessoa somente pode optar por aquilo que realmente ela conhece e tem a deliberação de rejeitar. Parece, todavia, não ser bem esse o caso dessas minorias.

A sociedade possui, ou ao menos impõe, um padrão hegemônico social, comportamental, moral, estético, econômico, psicológico, no qual diversas pessoas ou grupos de pessoas não estão incluídos. Por si só, já é um fator excludente (MINHOTO, 2013, p. 04). 
O que interessa para o campo do Direito é que a sociedade não veja tais pessoas com estereótipos, muito menos com agir discriminatório, porque, antes de serem integrantes de qualquer grupo, são seres humanos e têm o direito de serem aceitos e protegidos tanto pelo Estado como pela sociedade civil.

No cenário internacional, ao longo da história, casos de segregação racial protagonizaram momentos marcantes das sociedades. Pode-se citar, como exemplo, os judeus na Alemanha nazista, os curdos quase dizimados pelo Iraque de Sadam Husseim e, mais recentemente, de forma menos severa, a discriminação sofrida pelos árabes-muçulmanos em França, ora hostilizados pelo seu credo (MINHOTO, 2013, p. 8), assim como dos refugiados de guerra.

Percebe-se, então, que, conquanto essa exclusão ocorra em graus elevados ou menos, ela precisa de atenção, pois uma sociedade deve, antes de qualquer análise, assegurar o respeito para com o próximo, seja em função da cultura, língua, origem, crença, seja qual for a razão. É preciso ter em mente que uma sociedade é feita de pessoas, todas são seres humanos, iguais na humanidade, embora com derivações desiguais.

Para Anjos Filho, alguns caracteres são constitutivos ou delineadores das minorias. São eles: o elemento diferenciador, o elemento quantitativo, o elemento de nacionalidade, o elemento da não-dominância e o elemento da solidariedade (ANJOS FILHO, apud MINHOTO, 2013, p. 09). O referido autor ensina que, quando um grupo luta para preservar suas características, seus costumes, sua língua, o faz com caráter de solidariedade, no sentido de obter uma aceitação mais ampla.

Assim, cria-se um paradoxo, pois, de um lado, se tem a parte interna do grupo que se desenvolve pela aceitação uns com os outros com o espírito de solidariedade, fora do grupo o que geralmente ocorre é o contrário. Assim, fora do grupo, pelo fato de se tratar de seres diferentes ou destoantes da maioria, estes sofrem discriminação.

\section{DO MEIO EXTERNO EQUILIBRADO COMO FATOR PREPONDERANTE PARA O DESENVOLVIMENTO DA PERSONALIDADE}

O ser humano necessita de um habitat para viver e se desenvolver, mas o meio ambiente deve estar em condições adequadas e salubres para que a pessoa consiga desenvolver suas capacidades e habilidades e, assim, viver com dignidade. É cediço, assim, que 
não há como o homem sobreviver sem água, sem ar respirável, em um ambiente modificado e degradado pelas suas próprias mãos.

O meio ambiente é constantemente alterado pelo homem em razão do crescimento econômico desordenado. Resta, portanto, ao Direito o papel de intervir nas relações e nas atividades humanas para assegurar a proteção e a preservação do meio ambiente de forma sistêmica e orgânica, o que se realiza por meio das normas do Direito Ambiental.

O valor que sustenta a norma ambiental é o reflexo no mundo ético das preocupações com a própria necessidade de sobrevivência do ser humano e com a proteção da saúde do meio ambiente, com a conservação das espécies, a proteção das águas, do solo, das florestas, do ar, ou seja, do que for imprescindível para a vida (ANTUNES, 2014, p. 5).

Paulo de Bessa Antunes ensina que o Direito Ambiental não trata só da natureza, pois o meio ambiente compreende também a atividade antrópica e, ainda, a atividade produzida pelo homem sobre o meio físico de onde ele retira seu sustento, daí o autor entender que o homem é parte deste meio natural (ANTUNES, 2014, p. 7).

Muito embora o Direito Ambiental esteja intimamente ligado à ordem econômica, a maior preocupação será quanto à sua vertente humanística, tendo em vista o acesso equitativo de todos ao meio ambiente ecologicamente equilibrado, em razão de seu status fundamental e também da inclusão ambiental aos socialmente excluídos.

Como já visto alhures, o art. 225 da Constituição Federal de 1988 estabelece que "todos têm o direito ao meio ambiente ecologicamente equilibrado [...]" (BRASIL, 1988) e a referência a "todos" implica toda e qualquer pessoa, sem nenhuma limitação, sejam ricos, pobres, brancos, negros, índios, deficientes, crianças, homens e mulheres.

Apesar disso, não é essa a realidade que se tem visto, pois, em razão do avanço imobiliário, tecnológico, de buscar o crescimento exagerado, tanto as empresas privadas como entes públicos invadiram a natureza e priorizaram as melhores condições de ambiente àqueles que têm recursos financeiros, excluindo deliberadamente vários segmentos do acesso à natureza. São grupos que sequer podemos denominar de minorias, pois, no caso, não há ligação entre as pessoas que tomam parte deles, muito provavelmente já excluídas socialmente e com pouca preocupação quanto à questão ambiental.

O objetivo da Constituição Federal de 1988 é a construção de uma sociedade livre, justa, solidária e sem preconceitos, mas o que se vê é uma sociedade na contramão da força normativa da Constituição (ANTUNES, 2014, p.7), porquanto não há uma correspondência entre 
as normas constitucionais e a realidade em face de a questão ambiental ser relegada a segundo plano com relação às pessoas mais vulneráveis.

O meio ambiente equilibrado é essencial para a vida saudável e, por tal motivo, é bem comum de todos, um direito fundamental, pois não há vida sem ele. Sobre a tutela deste bem, garante-se que esta possa ser feita por todos mediante ação coletiva, conforme o disposto no art. 5ㅇ, inciso LXXIII, da Constituição de 1988. É, como já visto alhures, um direito fundamental alicerçado no princípio da dignidade da pessoa humana, uma vez que, no centro gravitacional do Direito Ambiental, está o ser humano:

O reconhecimento de tutela a bens jurídicos que não estejam diretamente vinculados à pessoa humana é um aspecto de grande importância para que se possa medir o real grau de codependência entre homem e o mundo que o cerca, do qual ele é parte integrante e sem o qual não logrará sobreviver. A atitude de respeito e proteção às demais formas de vida ou aos sítios que as abrigam é uma prova de compromisso do ser humano com a própria raça e, portanto, consigo mesmo. (ANTUNES, 2014, p. 20)

O Brasil ainda permanece na tentativa de construir os contornos de um mínimo necessário para se viver com dignidade, ainda embasado na concepção de que o homem está em uma posição superior a dos animais, de somente o ser humano ter o dom da racionalidade, transformação consciente da natureza (ANTUNES, 2014, p. 25) e, ainda, ser o único dos seres feito à semelhança de Deus (GONÇALVES, 2008, p. 42).

O homem, conforme estabelecido na Constituição Federal de 1988 e na Declaração do Rio, é o centro das preocupações do Direito Ambiental, que tem como fim o ser humano, com a preocupação de que este possa viver em condições melhores (ANTUNES, 2014, p. 25).

Os principais problemas ambientais em todo o globo terrestre ocorrem sempre em regiões mais pobres, nas quais a maioria das vítimas são pessoas desafortunadas. Por óbvio, então, a condição ambiental somente pode ser melhorada, no sentido de proporcionar melhor qualidade de vida, se houver, de fato, uma melhora na distribuição de rendas e políticas públicas eficientes.

O Brasil, por ser um país em desenvolvimento, tem um emaranhado de leis que buscam a tutela ambiental efetiva, no entanto com pouca aplicabilidade, de modo a não impedir e até por vezes favorecer situações de injustiça para com muitas pessoas.

Frisa-se que o Brasil é signatário da Declaração sobre Direito ao Desenvolvimento, que dispõe, no artigo $1, \S 1$, que o direito ao desenvolvimento é um direito inalienável, em virtude do qual todas as pessoas e todos os povos estão habilitados a participar do desenvolvimento 
econômico, social, cultural e político, a ele contribuir e dele desfrutar, para que todos os direitos humanos e liberdades fundamentais possam ser plenamente realizados.

\section{DA TUtela dE PESSOAS VULNERÁVEIS EM RAZÃO DA DISCRIMINAÇÃo AMBIENTAL}

Atualmente, percebe-se o surgimento de uma nova figura de exclusão social, denominada neste estudo de discriminação ambiental. A expressão "racismo ambiental" tem sido, no entanto, mais empregada nas ciências sociais, porquanto aspectos próprios do racismo são transferidos e assumidos na roupagem de uma discriminação que se vê de forma mais ampla, principalmente no referente a aspectos ambientais e do habitat.

Para conceituar racismo, poderia ser utilizado o pensamento dos antigos gregos, os quais acreditavam ser bárbaros, "diferentes", quem estava fora da polis, em especial os não gregos. Outrossim, as populações vencidas e incorporadas por um povo dominante ficavam marginalizadas. Dessa forma, são essas as primeiras conformações que o termo adquire no Ocidente, indicando exclusão.

Bem mais recente, o termo "racismo" indica e afirma a superioridade de um grupo racial em relação aos outros, preconizando práticas que variam do isolamento, escravidão, assimilação, até o extermínio de minorias (PEREIRA; BROUWES, 2011, p. 25). O racismo, conforme Bobbio, Mateucci e Pasquino (2000, p. 1059), é “[...] o uso político de alguns resultados aparentemente científicos, para levar à crença da superioridade de uma raça sobre as demais. Este uso visa a justificar e consentir atitudes de discriminação e perseguição contra as raças que se consideram inferiores".

Estudos em universidades norte-americanas vieram a revelar uma associação da prática do racismo com determinadas ações e omissões para desfavorecer afroamericanos em matéria ambiental. Adveio a expressão racismo ambiental, originalmente empregada nos Estados Unidos da América, primeiramente em razão da moradia de negros em locais ambientalmente comprometidos, mas, depois, para também abarcar outros segmentos ecologicamente excluídos da população em virtude da discriminação:

Esse clamor por Justiça Ambiental começou a ser organizado nos Estados Unidos, como iniciativa de cidadãos e como campo teórico/acadêmico, depois do caso de contaminação química em Love Canal, Niagara, Estado de Nova York. Lá, a partir de 1978, moradores de um conjunto habitacional de classe média baixa descobriram que suas casas haviam sido erguidas junto a um canal que tinha sido aterrado com dejetos químicos industriais e bélicos (LEVINE, 1979; LEVINE, 1982; GIBBS, 1998). 
Pouco depois, em 1982, moradores da comunidade negra de Warren County, Carolina do Norte, também descobriram que um aterro para depósito de solo contaminado por PCB (polychlorinated bipheny/s) seria instalado em sua vizinhança. Data daquele ano o primeiro protesto nacional feito pelos afro-americanos contra o que chamaram de 'racismo ambiental'. A partir daí, o movimento negro norte-americano sensibilizou congressistas, e o US General Accounting Office conduziu uma pesquisa que mostrou que a distribuição espacial dos depósitos de resíduos químicos perigosos, bem como a localização de indústrias muito poluentes nada tinham de aleatório: ao contrário, se sobrepunham à distribuição territorial das etnias pobres nos Estados Unidos e a acompanhavam. [...].

Não apenas os negros são o alvo da prática de localização dos depósitos de resíduos perigosos e de incineradores: segundo Bullard, na Califórnia, a zona de ocupação latina do leste de Los Angeles e de Kettleman (uma comunidade rural de cerca de 1.500 habitantes, das quais 95\% são latinos) também é alvo dessas escolhas. 0 mesmo se diz dos povos indígenas: mais de 36 reservas indígenas receberam aterros e incineradores. Em 1991, os Choctaws da Filadélfia e do Mississippi conseguiram derrotar um projeto de alocar um aterro de lixo de 466 acres em seu meio. Naquele mesmo ano, a reserva de Rosebud, em Dakota do Sul, se viu ameaçada por uma empresa de Connecticut que se propunha a construir ali um aterro de lixo de 6 mil acres. Os cidadãos norte-americanos afetados passaram a se organizar em coalizões nacionais. [...]. (HERCULANO, 2008)

O termo racismo ambiental é empregado às injustiças sociais e ambientais que recaem

de forma implacável sobre etnias e populações mais vulneráveis, de maneira que isto ocorre para diferenciar, de forma prejudicial, os grupos e etnias vulneráveis que são atingidos por políticas ou práticas discriminatórias, como, por exemplo, os povos indígenas, agricultores familiares, ribeirinhos, pescadores artesanais e outros representantes de populações tradicionais, fazendo com que estes subsistam só em locais isolados e destituídos de qualquer riqueza, sendo-lhes concedido apenas o território como forma de exílio (PACHECO, 2008).

As pessoas integrantes de tais contingentes não deveriam ser consideradas de forma abstrata, pois possuem características que evidenciam o pertencimento a segmentos étnicoraciais e, dessa forma, suas identidades culturais não deveriam ser subestimadas.

Percebe-se agora que o racismo ambiental extrapola questões meramente raciais e étnicas, abarcando as injustiças, os preconceitos e as desigualdades que afligem não apenas minorias negras, mas também as populações de outros grupos vulneráveis (ABREU; MOREIRA, 2014, p. 76). No referente ao racismo ambiental, nas palavras de Pereira e Brouwers (2011, p. 79), o fenômeno é caracterizado como "uma modalidade de discriminação a determinadas pessoas ou grupos sociais", obrigados a suportar os efeitos da discriminação desigual dos riscos 
ambientais. Deve-se entender, portanto, que a expressão racismo ambiental é restrita, de maneira que é mais adequada a denominação de discriminação ambiental.

É notório que a realidade brasileira esteja alicerçada em grande injustiça e desamparo social, mas pouco se tem dito acerca de ambientalmente desamparados. As pessoas que fazem parte de minorias e grupos vulneráveis já são, via de regra, desamparadas socialmente, porém, ainda mais, pois são submetidos a uma dupla carga de injustiça, ao ocuparem morros, lixões, lugares totalmente inadequados para se viver e formar uma família.

Como se formará a personalidade de uma criança criada nesse cenário, ou seja, em ambientes sem água potável, sem saneamento básico, sem ar saudável, com solo contaminado, em suma, excluída socialmente? Qual o peso que o meio externo exerce sobre o desenvolvimento da personalidade?

O Brasil, em sua imensidão territorial, possui vários ecossistemas e regiões com diferentes problemas ambientais. Uma região na qual certamente se vê a maior vulnerabilidade é o sertão nordestino, onde seres humanos vivem isolados em meio a terras improdutivas devido à aridez, sem água para consumo ou para o plantio. Na Região Norte, a pobreza também castiga drasticamente as populações ribeirinhas, em especial as famílias formadas apenas por mulheres e crianças, que se prostituem inclusive para obter alimentos quando cruzam os barcos nos mananciais. Em todas as regiões, nas grandes cidades, as pessoas que moram em favelas não têm acesso a uma série de serviços, o mesmo ocorrendo com uma parcela da população rural. As pessoas quedam totalmente à mercê de políticas públicas por um governo que os trata, muitas vezes, como invisíveis em face das reais necessidades, observadas apenas em épocas de eleição.

O que se verifica agora é uma discriminação ambiental praticada também por quem está no governo ou no exercício de funções estatais, pois não cuida da realidade desses cidadãos. É público e notório que as pessoas que habitam essas regiões e áreas sofrem com diversas epidemias, pois lá não tem bons hospitais, não chegam remédios e vacinas, não têm água potável para beber, não tem alimentos saudáveis para ingerir, os filhos desses cidadãos morrem de desnutrição e, por vezes, até animais morrem de fome ou de sede. O fato é que se vê, há muito tempo, essa realidade e nada efetivo ou muito pouco é feito para mudar o cenário, em especial no que tange às causas que geram a exclusão.

No Brasil, até mesmo as decisões judiciais, por vezes, carecem de justiça. Normalmente, conferem, até intuitivamente, privilégios para alguns e deixam de lado pessoas que fazem parte dos grupos vulneráveis, principalmente os financeiramente desamparados (FORUM CENTRO 
VIVO, 2006, p. 29), desde a infância e a adolescência (ROCHA, 2013), porquanto habitualmente desprovidos de uma boa defesa em termos processuais, apesar da existência de direitos e garantias constitucionais e legais abstratamente assegurados (DOTTI, 2014).

O poder, pertencente ao povo nos termos do art. 1ํ, parágrafo único, da nossa Constituição, é exercido direta ou indiretamente pelos representantes eleitos (BRASIL, 1988), porém, para as pessoas excluídas, não há uma atuação de forma a proporcionar o mínimo necessário para viver com dignidade, de maneira que, na prática, a cidadania sofre com a falta de combinação entre os fundamentos constitucionalmente previstos para a República Federativa do Brasil.

Em que pese a análise do racismo sobre a questão ambiental, é imprescindível analisar a questão política, ou, ainda, uma vertente dela, denominada de biopolítica, defendida por Michel Foucault, com a seguinte explicação:

Trata-se de um conjunto de processos como a proporção dos nascimentos e dos óbitos, a taxa de reprodução, a fecundidade de uma população, etc. São esses processos de natalidade, de mortalidade, de longevidade que, justamente na segunda metade do século XVIII, juntamente com uma porção de problemas econômicos e políticos [...], constituíram, acho eu, os primeiros objetos de saber e os primeiros alvos de controle dessa biopolítica. (FOUCAULT, apud ABREU, 2013)

Em sua análise, o filósofo francês mencionou que a relação dos processos naturais e acidentais da população com questões econômicas, sociais e políticas caracterizam a biopolítica, ao passo que a inserção do fator biológico nos mecanismos de poder constitui o biopoder. Então, biopoder é "o conjunto dos mecanismos pelos quais aquilo que, na espécie humana, constitui suas características biológicas fundamentais vai poder entrar numa política, numa estratégia política, numa estratégia geral de poder" (FOUCAULT, apud ABREU, 2013).

Mortalidade, natalidade, doenças, epidemias, fome, saúde pública, imigração, habitação, xenofobia e racismo são problemas biopolíticos a serem enfrentados pelos governos nacionais, que mereceriam grande peso nas tomadas de decisões (FOUCAULT, apud ABREU, 2013).

Assim, diante de um Estado que não prioriza politicamente os mais vulneráveis e que os exclui socialmente, o racismo impera com desvalor social. Não obstante, o racismo deixa de ter apenas impacto racial, estendendo o preconceito ao nível de discriminação em face das ações e omissões injustas ocorridas para com grupos vulneráveis, incapazes de se protegerem e de administrarem suas vidas, mormente pelo fato de serem dependentes de ajuda do Estado, que, muitas vezes, falha nesse mister. 
Ivy de Souza Abreu (2014, p. 79), considerando a realidade brasileira, acrescenta que o racismo é a forma pela qual desqualificamos o outro e o anulamos, enxergando-o como "não semelhante". Segundo o autor, o racismo faz aceitar a pobreza e a vulnerabilidade de enorme parcela da população brasileira, com pouca escolaridade, sem renda, sem políticas sociais de amparo e de resgate, simplesmente porque se internalizam tais diferenças. Em verdade, tratase da forma mais recente de discriminação, não apenas racial, porquanto também atinge os mais pobres.

A discriminação aos poucos foi se acentuando após o fim da Guerra Fria e a nova conformação geopolítica do mundo globalizado, ao colocar ricos e pobres em lados opostos por força de uma divisão política do mundo, que faz agora por desconsiderar valores caros à existência humana e à vida em geral, dependente do respeito ao meio ambiente (SILVA, 1994).

A maioria da população pobre vive em áreas ambientalmente vulneráveis, de terras áridas ou pouco produtivas, nas encostas dos morros, bem como em locais de grande poluição, até mesmo em locais onde ocorre a descarga de resíduos tóxicos e perigosos (SILVA, 1994). Nos centros urbanos, em especial nos subúrbios, estas pessoas vivem em lugares inadequados para a construção de moradias, próximas a córregos, esgotos, locais que alagam facilmente ou em morros (SILVA, 1994). Já as populações mais pobres no meio rural, por sua vez, encontram grande dificuldade para retirar o sustento delas da natureza. Estes cenários são bem ilustrados por Tania Pacheco (2008, p. 11-23).

O meio ambiente é, muitas vezes, destruído por modelos de desenvolvimento predatórios, baseados na busca do lucro a tudo custo e na exploração desenfreada de recursos naturais em detrimento das pessoas que habitam certas áreas (SILVA, 1994).

A discriminação ambiental traduz-se em todo o processo de alijar populações para áreas periféricas, sem saneamento básico e insalubres, nas quais o risco de adquirir doenças e de ter reduzida sua expectativa de vida são inevitáveis.

O problema do preconceito no Brasil já extrapolou as questões raciais e étnicas e se alastrou para além do convívio social, pois também está presente na vida política no país e nas decisões governamentais (ABREU, 2013, p. 87-99). A motivação para exclusão tem as mais variadas nuances, seja pela cor de pele, local de nascimento, tipo de trabalho ou ausência deste, local de residência, escolaridade, conta bancária e a crescente questão ambiental (ABREU, 2014, p. 80). 
Do racismo tradicional chega-se à discriminação para a compreensão da devida e necessária contextualização dos problemas sociais e ambientais, superando, assim, a mera questão racial e étnica do preconceito. Assim se deduz:

Na realidade atual [...] a injustiça e a discriminação ambientais ainda são uma grave preocupação na comunidade internacional e dentro dos Estados. [...]. No Brasil, isso é decorrência inevitável do profundo abismo socioeconômico existente entre as regiões geográficas ou geoeconômicas e, ainda mais, entre os seguimentos da sociedade. (MILARÉ, 2005)

A reflexão sobre o racismo ambiental explicita, por exemplo, o desmazelo com as periferias urbanas, bem como a ocupação ilícita das reservas indígenas, denunciando a situação-limite de populações ribeirinhas, entre outros propósitos (BENJAMIN, apud INOCÊNCIO, 2013, p. 48). A presença indígena em centros urbanos, sem qualquer alternativa nem de renda, nem de vida que não esteja atrelada à mendicância é uma consequência do racismo ambiental (PEREIRA; BROUWERS, 2011, p. 168), mas também da forma mais alargada, que é a discriminação ambiental.

O art. 231 da Constituição brasileira de 1988 reconhece aos índios a sua organização social, costumes, línguas, crenças e tradições, bem como os direitos originários sobre as terras que tradicionalmente ocupam. É dever da União demarcá-las, proteger e fazer respeitar todos

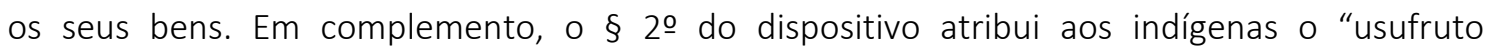
exclusivo" das riquezas do solo, dos rios e dos lagos existentes nas terras indígenas.

Pelo instituto do usufruto constitucional indígena, toda e qualquer atividade, que possa ser realizada em terras indígenas, necessariamente deve ter o consentimento prévio dos indígenas que as habitam. Ademais, a população indígena deveria participar do rendimento econômico da atividade econômica exercida, ou seja, em relação às terras, aos rios e aos lagos. Portanto, o acesso a estas terras não pode acontecer sem a consideração das disposições constitucionais próprias (ANTUNES, 2014, p. 795).

Na realidade prática, não é isto que acontece. Tem-se um contexto biopolítico de exclusão, em especial com a formação de grupos segregados por motivação ambiental, podendo-se afirmar que se instaurou um estado de exceção permanente, pois deixou de ser excepcional e, lamentavelmente, tornou-se regra (ABREU, 2013, p. 94).

Tem-se a doutrina do homo sacer ambiental, referente ao subcidadão pertencente ao grupo de pessoas excluídas ambientalmente (ABREU; MOREIRA, 2014, p. 76). Apenas para melhor situar o surgimento do homo sacer contemporâneo, ao avançar o contraponto entre o poder do Estado trabalhado por Hannah Arendt e o micropoder nos ambientes da sociedade abordado por Foucault, o filósofo Giorgio Agamben (2010, p. 18 e 35) revela que as pessoas 
socialmente inadequadas e irrelevantes deixam de ter valor para a sociedade e para o Estado, de maneira a serem excluídas do circuito do direito, abandonadas pela lei à própria sorte, como pessoas invisíveis à proteção estatal, como se fossem banidas da vida.

O Estado, com o seu poder soberano, não mata, mas deixa essas pessoas morrerem, pois, embora sejam portadoras de direitos fundamentais, são, dadas as suas condições de vida, postas em invisibilidade pela própria sociedade, de forma finalisticamente submetidas e esmagadas pelo processo produtivo ao qual está também reduzido o restante da sociedade. Não se pode, todavia, concordar com esse ônus decorrente do progresso, especialmente se realizado hoje de forma irresponsável, gerando danos que são suportados especialmente por grupos excluídos por questões de discriminação racial, étnica e econômica.

Resta imprescindível destacar que essa forma de discriminar se acentuou com a era da globalização hegemônica, fruto de um consenso estabelecido entre as grandes potencias econômicas mundiais, pautando-se em dois princípios: (a) o localismo globalizado - que se apresenta por meio de práticas bem sucedidas da globalização econômica, com objetivo de universalizar alguns estilos de vida e dar padrões ao consumo; (b) o globalismo localizado - que se apresenta por alterações que a universalização de padrões hegemônicos refletem em alguns locais. Seriam como hábitos transnacionais vivenciados (PEREIRA; BROUWERS, 2011, p. 48).

Para se conseguir essa transnacionalidade de padrões de vida e de consumo, o que primeiro se explora são os recursos naturais. Afinal, uma sociedade de consumo se perfaz com o avanço tecnológico e, para que isso ocorra, a sociedade precisa consumir cada vez mais os recursos ambientais.

Pode-se afirmar que as consequências dessa globalização hegemônica, que nada mais busca senão a padronização de sociedades de consumo, são o aumento das desigualdades, por meio do favorecimento de atividades econômicas internacionalizadas.

Para que um país em desenvolvimento, como o Brasil, possa se manter em padrões internacionais ditados pelos países desenvolvidos, os governantes e a própria sociedade decidem, ainda que não se perceba, adotar, paulatinamente, políticas e comportamentos de exclusão.

Uma das primeiras atitudes é colocar as pessoas das minorias e dos grupos vulneráveis, que não conseguem se proteger sozinhas, longe dos olhos da sociedade. Tudo para que a população padronizada não precise conviver com elas e, ainda, para que a sociedade não precise olhar para esta realidade. 
Tanto isso é verdade que os shopping centers, principalmente os mais luxuosos, procuraram inicialmente impedir a circulação, em seus corredores, de pessoas de baixa renda, principalmente se negras (RAMALHOSO, 2014), ou seja, nada que pudesse desagradar aos olhos ou fugisse dos padrões que esta sociedade considera como "social". O movimento dos rolezinhos, por exemplo, foi alvo de diversas críticas sociais (BOTTARI, 2014). Atualmente, quando muito, é a praça de alimentação dos shoppings o local destinado a estes jovens em finais de semana (FONSECA, 2005).

Os informes divulgados na Rio-92 foram conclusivos no sentido da existência da discriminação ambiental ou racismo ecológico. Destaca-se:

[...]. A Rio-92 apresentou dados que apontam uma nova visão de mundo: $60 \%$ da população pobre, de maioria negra, vive em áreas ecologicamente vulneráveis do planeta: terras áridas ou pouco produtivas, topos de montanhas, mangues, pântanos; nos centros urbanos, morros, lugares inadequados para a construção de moradias, no meio rural, onde dependem da natureza para sobreviver, são desestruturados por modelos de desenvolvimento predatórios, baseados na busca do lucro a todo custo e na exploração desenfreada dos recursos naturais. [...]. (SILVA, 1994)

Tendo em vista essa nova construção de discriminação, é necessário o desenvolvimento de ciências e uma melhor construção jurídica, para que efetivamente se faça algo para que o Brasil realmente se torne uma sociedade livre, justa e solidária, sem preconceitos de nenhuma forma. Entretanto, para que se chegue a essa valoração, mister se faz a implantação de políticas públicas eficientes e reais.

Não há como se referir à matéria de exclusão, tratá-la sem um viés multidisciplinar, pois o tema também envolve as ciências biológicas e várias ciências sociais e humanas, a ética e políticas públicas, com relação evidente com o Direito, pois a matéria exige uma proteção jurídica efetiva, especialmente por lei.

Somente quando as políticas públicas forem efetivas, numa abordagem ainda mais justa, talvez o cenário possa mudar. Para que este cenário realmente mude, todavia, é necessário primeiramente a imediata mudança de consciência quanto ao "outro", por meio da aceitação das diferenças e da inclusão socioambiental.

\section{CONCLUSÃO}

No presente trabalho, foi abordada a forma pela qual a sociedade moderna vem excluindo as pessoas em situação de vulnerabilidade social, as quais agora são duplamente 
excluídas, não só por serem pobres, mas também por se encontrarem em completo desamparo em razão de viverem em um meio ambiente ecologicamente desequilibrado.

Os excluídos foram analisados sob o aspecto da ausência da proteção das pessoas em razão das características que as diferem umas das outras no âmbito social. Demonstrou-se a necessidade de inclusão da sensibilidade na sociedade, para o fim de aceitar a diferença em obediência aos princípios fundamentais da igualdade e da dignidade humana. Na sequência, realizou-se um exame da discriminação frente ao princípio da isonomia.

Entendeu-se que o ordenamento precisa disciplinar de forma a garantir não somente os direitos da maioria, mas também os direitos das minorias, dispondo de tratamento compatível com as discrepâncias existentes. Para que isso ocorra, é imprescindível a busca pela justiça, de forma que se possa apresentar princípios fundantes gerais para garantir a igualdade para os mais variados grupos sociais, desde os mais vulneráveis, as massas populacionais identificadas, e as minorias.

A sociedade atual, produto do capitalismo e da globalização hegemônica, com padrões ideais, segrega os cidadãos e separa ferozmente os que se encontram em desigualdade social. Isso faz com que muitas pessoas sejam afastadas de um meio ambiente equilibrado e sejam jogadas à margem ambiental, onde não há condições de se desenvolverem da mesma forma que as demais.

Na concepção rawlsiana de justiça como equidade, pode-se entender que, na hipotética posição original, os membros da sociedade escolheriam iguais liberdades fundamentais para todos, assim como as desigualdades sociais e econômicas seriam justamente justificáveis apenas se o benefício para os mais favorecidos também permitissem certo proveito para os mais debilitados.

Sob esta compreensão de justo, em se tratando o meio ambiente de um direito difuso, pertencente, portanto a todos, há que se concluir como princípio o acesso equitativo aos recursos naturais, de forma a assegurar e a proteger as pessoas mais vulneráveis das condições ambientais adversas à saúde e à vida digna em razão da debilidade econômica. Tal proteção diz respeito não apenas às pessoas da atual geração, mas de seus descendentes e das gerações futuras.

Certas minorias e grupos vulneráveis, como é o caso dos negros, mulheres, indígenas, crianças, adolescentes, idosos, pessoas com deficiência, pessoas extremamente pobres, podem estar em situação de flagrante fragilidade social. Por isso, carecem de especial proteção para o exercício de sua cidadania mediante o direito fundamental a uma personalidade íntegra. 
Para tanto, é preciso implementar políticas públicas e até mesmo ações afirmativas gradativas para que a sociedade possa perceber que o diferente não deve ser repelido, mas compreendido e auxiliado pelos governantes e pelos demais cidadãos, principalmente por parte das pessoas e empresas que fazem maior uso permitido dos recursos e bens ambientais.

O Estado deve atuar de forma a efetivar direitos fundamentais para que as pessoas tenham acesso a uma vida digna. Há a necessidade de o Poder Público, de forma positiva, agir para que todos os indivíduos, independentemente de pertencerem ou não à maioria, possam exercer seus direitos plenamente.

As políticas públicas e as ações afirmativas anti-discriminação seriam um modo encontrado para que situações desiguais sem justificativa pudessem ser equiparadas, observando sempre os princípios constitucionais. Devem as políticas públicas ser observadas e constantemente reavaliadas, sob pena se tornarem, elas próprias, uma forma de discriminação ao longo do tempo.

A justiça se traduz em tratar igualmente as pessoas que se encontram em condições iguais e, principalmente, tratar de forma diferenciada os indivíduos que necessitam de tratamento diferenciado ou especial, em decorrência da sua fragilidade e da sua vulnerabilidade, pois esses motivos impedem os "diferentes" de terem as mesmas condições, chances e oportunidades que os demais.

Somente com ações desta envergadura, o Estado logrará a construção de uma sociedade, livre, justa e solidária, sem discriminação, conforme os objetivos pautados no art. 3o da Constituição da República Federativa do Brasil de 1988.

\section{REFERÊNCIAS}

ABBOUD, Georges; CARNIO, Henrique Garbellini; OLIVEIRA, Rafaela Tomaz de. Introdução à teoria e a filosofia do Direito. São Paulo: Revista dos Tribunais, 2013.

ABREU, Ivy de Souza. Biopolítica e racismo ambiental no Brasil: a exclusão dos cidadãos. Revista Opinión Jurídica. Medellin, v. 12, n. 24, p. 87-99, jul./dic. 2013. Disponível em: <http://www.scielo.org.co/scielo.php?pid=S1692-25302013000200006\&script=sci_arttext>. Acesso em: 26 jul. 2015. Cf.: <http://www.scielo.org.co/pdf/ojum/v12n24/v12n24a06.pdf >. Acesso em: 17 set. 2017.

ABREU, Ivy de Souza; MOREIRA, Nelson Camatta. Exclusão Ambiental, Subcidadania e Biopolítica no Brasil. In.: Revista de Direito Ambiental. São Paulo: Revista dos Tribunais, ano 19, 2014.

AGAMBEN, Giorgio. Homo sacer: o poder soberano e a vida nua I. Tradução de Henrique Burigo. 2. ed. Belo Horizonte: Ed. UFMG, 2010. 
AMARAL, Larissa Maciel do; GOMES, Mariana de Queiroz. O despertar ambiental: construção de uma nova cidadania. In.: MENDONÇA, Maria Lirida Calou de Araujo e; PAGLIARINI, Alexandre Coutinho; KOSIKOSKI, Sandro Marcelo (Coords.). Direito Ambiental II. Florianópolis: FUNJAB, 2012, p. 165-184. [XXI Congresso Nacional do CONPEDI/UFF, Niterói, RJ, 2012]. Disponível em: <http://www.publicadireito.com.br/artigos/?cod=096d3a817a272647>. Acesso em: 19 jul. 2015.

ANTUNES, Paulo de Bessa. Direito Ambiental. 16. ed. São Paulo: Atlas, 2014.

BARBOSA, Haroldo Camargo. Meio Ambiente, Direito Fundamental e da Personalidade. In.: LECEY, Eladio; CAPPELLI, Silvia (Coords.). Revista de Direito Ambiental. São Paulo: Revista dos Tribunais, ano 17, n. 68, p. 49-74, out./dez. 2012.

BARROSO, Luís Roberto. A dignidade da pessoa humana no Direito Constitucional contemporâneo: a construção de um conceito jurídico à luz da jurisprudência mundial. Tradução de Humberto Laport de Mello. Belo Horizonte: Fórum, 2013.

BITENCOURT NETO, Eurico. O Direito ao mínimo para uma existência digna. Porto Alegre: Livraria do Advogado, 2010.

BOBBIO, Norberto; MATEUCCI, Nicola; PASQUINO, Gianfranco. Dicionário de Política. 5. ed. Tradução de João Ferreira. Brasília: Ed. UNB, 2000, vol. 2.

BOTTARI, Elenilce. Rolezinho derruba movimento em Shopping Leblon. O Globo, Rio de Janeiro, 21 jan. 2014. Disponível em: <http://oglobo.globo.com/rio/rolezinho-derruba-movimento-noshopping-leblon-11355905>. Acesso em: 15 abr. 2015.

BRASIL. Constituição (1988). Constituição da República Federativa do Brasil de 1988: promulgada em 5 de outubro de 1988. Disponível em: <http://www.planalto.gov.br/ccivil_03/constituicao/constituicaocompilado.htm>. Acesso em: 19 jul. 2015.

Lei n. 6.938, de 31 de agosto de 1981. Dispõe sobre a Política Nacional do Meio Ambiente, seus fins e mecanismos de formulação e aplicação, e dá outras providências. DOU, Brasília, 02 set. 1991. Disponível em: <http://www.planalto.gov.br/ccivil_03/leis/L6938.htm>. Acesso em: 19 jul. 2015.

Supremo Tribunal Federal. Plenário. Mandado de Segurança n. 22.164-0/SP. Relator: Ministro Celso de Mello. Impetrante: Antônio de Andrade Ribeiro Junqueira. Impetrado: Presidente da República. Brasília, 30 de outubro de 1995. Votação unânime. DJ, Brasilia, 17 nov. 1995. Disponível

em $<$ http://redir.stf.jus.br/paginadorpub/paginador.jsp?docTP=AC\&doclD=85691>. Acesso em: 19 jul. 2015.

Supremo Tribunal Federal. Plenário. Ação Direta de Inconstitucionalidade n. 3.540-1/DF. Relator: Ministro Celso de Mello. Requerente: Procurador-Geral da República. Requerido: Presidente da República. Brasília, 01 de setembro de 2005. Maioria. DJ, Brasília, 03 fev. 2006. Disponível em <http://redir.stf.jus.br/paginadorpub/paginador.jsp?docTP=AC\&doclD=387260>. Acesso em: 15 abr. 2015.

CANOTILHO, José Joaquim Gomes; LEITE, José Rubens Morato. Direito Constitucional Ambiental brasileiro. São Paulo: Saraiva, 2007. 
CAPELO DE SOUSA, Rabindranath Valentino Aleixo. O Direito geral de personalidade. Coimbra: Coimbra Editora, 2011.

DOTTI, René Ariel. O pobre no direito e processo penal. Revista USP. São Paulo, n. 101, p. 45-54. mar./maio $2014 . \quad$ Disponível em: <https://www.revistas.usp.br/revusp/article/viewFile/87813/90735>. Acesso em 08 nov. 2017.

DWORKIN, Ronald. O império do Direito. Tradução de Jefferson Luiz Camargo. São Paulo: Martins Fontes, 1999.

FONSECA, Maria de Lourdes Pereira. Padrões sociais e o uso do espaço público. Caderno CRH. Salvador, BA, v.18, n. 45, p. 377-394, set./dez. 2005. Disponível em: $<$ https://portalseer.ufba.br/index.php/crh/article/view/18533/11909>. Acesso em 09 nov. 2017.

FORUM CENTRO VIVO. Violação de direitos humanos no centro de São Paulo: propostas e reivindicações para políticas públicas. Dossiê de denúncia. São Paulo, [2006]. Disponível em: <http://www.polis.org.br/uploads/977/977.pdf>. Acesso em: 08 nov. 2017.

GONÇALVES, Diogo Costa. Pessoa e Direitos da Personalidade. Fundamentação ontológica da tutela. Coimbra: Almedina, 2008.

HABERMAS, Jürgen. A inclusão do outro. Tradução de George Spencer e Paulo Astor Soethe. São Paulo: Loyola. 2002.

HERCULANO, Selene. O clamor por justiça ambiental e contra o racismo ambiental. InterfacEHS Revista de Gestão Integrada em Saúde do Trabalho e Meio ambiente. São Paulo: SENAC, v. 3, n. 1, Artigo 2, jan./abr. 2008.2 Disponível em: <http://www3.sp.senac.br/hotsites/blogs/InterfacEHS/wp-content/uploads/2013/07/art-22008-6.pdf>. Acesso em: 11 out. 2015.

HESSE, Konrad. A força normativa da Constituição. Porto Alegre: Sergio Antonio Fabris, 1991.

INOCÊNCIO, Nelson. Racismo ambiental: derivação de um problema histórico. ECO Brasília. Brasília: Inove, ano 1, no 1, p. 48, jul./ago. 2013. Disponível em: <http://www.ecobrasilia.com.br/ecobrasilia1.pdf>. Acesso em: 11 out. 2015.

KANT, Immanuel. Fundamentação da metafísica dos costumes e outros escritos. Tradução de Leopoldo Holzbach. São Paulo: Martin Claret, 2006.

KRELL, Andreas Joachim. Art. 225, caput. In.: CANOTILHO, J. J. Gomes; MENDES, Gilmar Ferreira; SARLET, Ingo Wolfgang; STRECK, Lenio Luiz. Comentários à Constituição do Brasil. São Paulo: Saraiva; Brasília: IDP; Coimbra: Almedina, 2013.

LUHMANN, Niklas. Sociologia do Direito. Rio de Janeiro: Tempo Brasileiro, 1983, v. II.

MACHADO, Paulo Affonso Leme. Direito ambiental brasileiro. 13 eds. São Paulo: Malheiros, 2005. 
MILARÉ, Édis; LOURES, Flávia Tavares Rocha. Meio Ambiente e os direitos da personalidade. Revista de Direito Ambiental. São Paulo: Revista dos Tribunais, ano 10, no 37, p. 11-27, jan./mar. 2005. Disponível em: <http://www.buscalegis.ufsc.br/revistas/files/anexos/26838-26840-1PB.pdf>. Acesso em: 17 set. 2017.

MINHOTO, Antonio Celso Baeta. Da escravidão às cotas: A ação afirmativa e os negros no Brasil. Birigui: Boreal, 2013.

MIRANDOLA, Giovanni Pico della. Discurso sobre a dignidade do homem. Tradução de Maria de Lourdes Sirgado Ganho. Lisboa: Edições 70, 2006.

OTERO, Cleber Sanfelici. Inclusão social da extrema pobreza: direito à cidadania integral e contextualização do mínimo necessário no Brasil. 2011. 444 f. Tese (Doutorado em Direito) Instituição Toledo de Ensino de Bauru, Bauru, SP.

PACHECO, Tania. Racismo ambiental: expropriação do território e negação da cidadania. In.: SRH (Org.). Justiça pelas águas: enfrentamento ao racismo ambiental. Salvador: Superintendência de Recursos Hídricos, 2008, p. 11-23. Combate ao racismo ambiental. Disponível em: <http://racismoambiental.net.br/textos-e-artigos/racismo-ambientalexpropriacao-do-territorio-e-negacao-da-cidadania-2/>. Acesso em: 17 set. 2017.

Inequality, Environmental Injustice, and Racism in Brazil: Beyond the Question of Colour". In.: Development in Practice. v.18, n.6, p. 713-725, aug. 2008. Racismo ambiental. Disponível em: <http://racismoambiental.net.br/textos-e-artigos/textos-e-artigostania-pachecoinequalityenvironmental-injustice-and-racism-in-brazil-beyond-the-question-of-colour/>. Acesso em: 17 set. 2017.

PEREIRA, Reginando; BROUWERS, Silvano do Prado. Sociedade de Risco Ambiental na Globalização. Revista de Direito Ambiental. São Paulo: Revista dos Tribunais, n. 16, 2011.

PRIEUR, Michel. Droit de l’environnement. 5. ed. Paris: Dalloz, 2004.

RAMALHOSO, Wellington. Shopping de luxo fecha as portas, e manifestantes fazem BO por racismo. UOL Notícias. São Paulo, 18 jan. 2014. Disponível em: $<$ https://noticias.uol.com.br/cotidiano/ultimas-noticias/2014/01/18/jk-iguatemi-fecha-asportas-contra-protesto-e-manifestantes-prometem-registrar-bo.htm>. Acesso em: 08 nov. 2017.

RAWLS, John. Justiça e eqüidade. In.: MAFFETONE, Sebastiano; VECA, Salvatore (Orgs.). A ideia de justiça de Platão a Rawls. Tradução de Karina Jannini. São Paulo: Martins Fontes, 2005, p. 385-443.

ROCHA, Andréa Pires. Protecionismo e a criminalização de adolescentes pobres por tráfico de drogas. Serviço Social \& Sociedade. São Paulo: Cortez, n. 115, jul./set. 2013. Disponível em: $<$ http://www.scielo.br/scielo.php?script=sci_arttext\&pid=S0101-66282013000300009>. Acesso em: 08 nov. 2017.

SARLET, Ingo Wolfgang. Direitos fundamentais em espécie. In.: SARLET, Ingo Wolfgang; MARINONI, Luiz Guilherme; MITIDIERO, Daniel. Curso de Direito Constitucional. São Paulo: Revista dos Tribunais, 2012. 
A Eficácia dos Direitos Fundamentais. 12. ed. Porto Alegre: Livraria do Advogado, 2015.

SILVA, José Afonso. Direito Ambiental Constitucional. 10. ed. Malheiros: São Paulo, 2013.

SILVA, Martiniano J. Origens, modalidades e formas de racismo. In.: Coleção Princípios. São Paulo: CDM Fundação Maurício Grabois, n. 34, 01 ago. 1994. Disponível em: $<$ http://grabois.org.br/portal/cdm/revista.int.php?id_sessao=50\&id_publicacao=133\&id_indice $=650>$. Acesso em: 26 jul. 2015.

SIRVINSKAS, Luís Paulo. Manual de Direito Ambiental. 12. ed. São Paulo: Saraiva, 2014.

TOMÁS DE AQUINO. Suma teológica. Tradução de Alexandre Corrêa. 2. ed. Porto Alegre: Livraria Sulina, 1980, v. II.

Trabalho enviado em 18 de setembro de 2017.

Aceito em 15 de novembro de 2017. 